Leslie McCartney \& Gwich'in Social and Cultural Institute*

\title{
Tails on the Trails
}

In 1996, the then Gwich'in Social and Cultural Institute (GSCI) in the Northwest Territories, Canada, published a strategic plan entitled Into the Next Millennium. ${ }^{1}$ The plan outlined projects the GSCI wished to undertake from 1996 to 2001 that would help achieve their mandate to "document, preserve and promote the practice of Gwich'in culture, language, traditional knowledge and values."

One of the identified projects was "Biographies of Prominent Elders." In preparing the strategy, the GSCI Board and Elders in the four Gwich'in communities of Aklavik, Inuvik, Fort McPherson, and Tsiigehtchic had expressed their wish that this project be undertaken. The Elders wanted their grandchildren to know their stories so the children would learn about and take pride in their traditional culture. The Elders also wanted a larger audience to learn about and from them, and to know their history. The goal of the project was to publish the stories, hopefully in a variety of ways such as a large book, a series of children's books based on themes, individual biographies of each Elder, or in journals for broader audiences. The GSCI asked Leslie McCartney-then a mature graduate student studying cultural

* now the Gwich'in Tribal Council Department of Cultural Heritage 
anthropology and oral history at Trent University in Ontario-to be the lead on the project.

Between 1999 and 2001, McCartney, along with Gwich'in Elder Therese Remy Sawyer (Terry) - a fluent Dinjii Zhu' Ginjik speaker who acted as a translator and cultural interpreter on the projectinterviewed twenty-three Gwich'in Elders in the four communities. Using oral history interviewing methodology, almost sixty hours of the Elders' life stories were recorded; some of the recordings were purely in Dinjii Zhu' Ginjik, others purely in English, others in a mixture of both languages. Remy-Sawyer completed oral translations of the Dinjii Zhu' Ginjik recordings and, almost fifteen years later, they were translated again by other Dinjii Zhu' Ginjik speakers into written English. The English transcripts were completed by a number of transcribers in the community, including by McCartney herself, adhering to a transcription template McCartney designed for the project.

As always in oral history, the recording is the primary source, and the multiple translations and transcripts are, at best, only "a shallow reflection of a living, dynamic event," according to oral historian David K. Dunaway. The fluidity of the interview becomes frozen in text on a page. ${ }^{2} \mathrm{McC}$ artney compared the hundreds of pages of various translations line by line as she tried to reconstruct the stories recorded. This was done in the most respectful way using what oral historian Patricia Leavy describes as a creative process she calls an impressionistic writing approach ${ }^{3}$ wherein the researcher also becomes a storyteller in the story being told.

The final textual product of the Elders biographies project, completed almost twenty years after the first interview, is the almost 900 page book with a working title of Our Whole Gwich'in Way of Life Has Changed. Stories from the People of the Land. Gwich'in K'yuu Gwiidandài' Tthak Ejuk Gòonlih. Gwatat Gugwiindài' Guugwandak, authored by McCartney and the Gwich'in Tribal Council and soon to be published by the University of Alberta Press. ${ }^{4}$ The stories told by the Elders are rich in traditional knowledge-peppered with place names and descriptive of cultural practices such as tanning moosehides, making dry meat, making babiche (strips of moosehide to use as lacings in snowshoes), and "knitting" snowshoes. Some Elders frankly 
discuss their struggle with, and eventual success in overcoming, alcoholism, and reflect upon the struggles they see their youth trying to contend with today. The Elders wanted their stories used not only to entertain, but to educate their grandchildren and others about what they had experienced in life, not only individually but as a collective whole-and to remember what life was like for the Gwich'in people before and after the signing of Treaty 11 in 1921 and the signing of the Gwich'in Comprehensive Land Claim Agreement in 1992. ${ }^{5}$

The evolution and analysis of putting oral history on the page is beyond the scope of this article, but does need to be briefly discussed. Oral historian Valerie Yow states that biography can be considered a literary genre as well as one of history. ${ }^{6}$ In her updated Recording Oral History: A Guide for the Humanities and Social Sciences, Yow succinctly reflects on the problems that writers encounter when trying to reconstruct interviews and publish oral history testimony. How do we take the transcript of the recording-which may or may not have included false starts, repetitions, and the insertion of punctuation that can change meaning, and which may appear disjointed on the page as narrators jump between topics-and make it flow legibly to a reader while maintaining the words and rhythm of the narrator's sentences and manner of speech? Yow asserts that some historians

argue that you need only correctly convey the meaning, but what they publish after they have put the narrator's thoughts into their words is what they think was the meaning. Others argue that you have to put the prose in a form that the public can read easily. They prettify the text: correct the grammar, take out all false starts, rearrange to make the speech sound like a planned delivery ... The editor is implying, 'Here are the words of this narrator.' But they are not the narrator's words if the editor has changed them. ${ }^{7}$

In editing and rearranging oral history interviews into a readable story, story parts that may appear on various pages need to be rearranged so they are all in one place. Yow advises her audience to do the least tampering with the text but acknowledges that, in publication, it may be necessary to rearrange order; this is assuming, of course, 
that the interview was recorded in English. If it was not, then you have multiple translations and versions of the same story to contend with. Thus reconstructing and putting the Elders' oral history on the page consists of more than just the words spoken in the interview and represented on a transcript; multiple points of information, as noted below, are incorporated to tell their story.

What follows are five short stories told by Gwich'in Elders Caroline Andre, Annie Benoit (Koe), Alfred Semple, Joan Nazon (Husky), and Jim Vittrekwa. Their stories told here are not just from the recorded sessions, but were repeated several times, with varying amounts of detail, over many cups of tea on the visits McCartney made as a community member. These were some of the Elders' favourites, that made them laugh as they remembered and related their tails on the trails stories. In the stories told by Caroline, Annie, Alfred, and Jim McCartney has woven in threads from the various tellings she heard on many occasions; in Joan's story, although the text has been edited and rearranged somewhat, the story has been written almost exactly as Joan would have told it. ${ }^{8}$

\section{Candice is the Boss}

Caroline (Kendo) Andre's grandparents were Old Ts'ideht'i' and Marcrena. Ts'ideht'i's English name was Old Modeste. In the eyes of young Caroline, Old Modeste and Marcrena were old; they were so very, very old. They moved slowly, their faces were very wrinkled and etched with the deep lines of people who had lived their entire lives on the land. They even spoke in an old way; they spoke with an old dialect of Teet' it Gwich'in that was common in the 1800s. But being old didn't matter to Old Modeste and Marcrena, things just took more time to accomplish than it did when they were younger. They preferred to live out on the land in their tent and not in a house in the village of Tsiigehtchik. When Old Modeste and Marcrena were younger, they liked to move on the land with the seasons, but they didn't go as far now because they were so very, very old. Now they stayed most of the time at a place called Tajilgoq. In Gwich'in, name Tajilgǫ means islands facing each other; in English, it is known as Three Forks Lake. Today, you can see this lake when you drive along the Dempster Highway 
because Tajilgǫ is between Tsiigehtchic and Fort McPherson. TajilgǫQ was a good place for Old Modeste and Marcrena to stay because the lake was on an old dog team trail that people would use to go between Tsiigehtchic and Fort McPherson, so anyone using that trail, they would check on Old Modeste and Marcrena.

Old Modeste still had several dogs, and when he and Marcrena needed to go somewhere, they would travel by dog team. But oh, Old Modeste's dogs were very strong and naughty, and poor Old Modeste, he just didn't have the strength anymore to control his dogs, and the dogs knew this. When Old Modeste would go out and start to hitch up his dogs, they would get so excited to get running that they would just run off before he could properly hitch them up. Poor Old Modeste would just be left behind as his dogs ran off into the bush. But Old Modeste, he never gave up. He would slowly walk and walk on his snowshoes for miles, calling his dogs to come home to try and hitch them up again.

Old Modeste's best leader dog was Candice; he was the fastest dog Old Modeste had ever had. Candice was smart, he knew all the trails and knew how to find his way home, even in a snowstorm when the trail would be covered with snow. But Candice was very bossy and strong willed. He liked to boss the other dogs around too. Old Modeste was so old, slow and weak, that Candice would even boss him around. Candice just did what he wanted, when he wanted. He never listened to Old Modeste, not even when Old Modeste would pet him, feed him and talk gently to him in Gwich'in. No, Candice had a mind of his own. Candice was so strong and bossy that sometimes, when he was pulling Old Modeste and Marcrena in a toboggan along a trail, when they would get to a fork in the trail, Candice would go whatever way he wanted. He wouldn't listen to Old Modeste, whatever way Candice decided he wanted to go on, he did. Poor Old Modeste could not stop him and they would be pulled miles away from where they wanted to go. When they finally did stop, Old Modeste would gently turn Candice and team around, go back to the fork, and take the trail he wanted them to go on.

Other times, Candice would lead the dogs and go too fast. When they were going to go somewhere, Old Modeste would help Marcrena get settled into the sled. It took a long time to get ready because they 
could not move fast and their bodies were sore with age. Finally, Marcrena would be settled in the sled, all bundled up in blankets to keep her warm and her few belongings and supplies packed tightly around her. Then, she would hold Old Modeste's backpack on her knees so he didn't have to carry it. Old Modeste would hitch up the team, and with Candice in the lead, Old Modeste would slowly make his way and stand on the back of the sled. The dogs would be jumping and yelping to go and when Old Modeste gave the signal, off they would go. Candice would run faster and faster and the whole dog team would go faster and faster and poor Old Modeste didn't have the strength to hold them back. Old Modeste would then sometimes lose his balance on the back of the sled and fall off into the snow. The dogs would keep going and then the sled would tip and Marcrena would fall out onto the snowy trail and the dogs would keep going. There Old Marcrena would sit, bundled up, still in her blankets, still holding on to Old Modeste's backpack, and wait for Old Modeste to come along the trail and find her. When he would find her, it would take him a long time to help her up, and then, they would slowly walk together, trying to find the dogs.

One day, when Caroline was young, she was living with her parents in a little house on the side of the hill by Van Tsal (in English it is known as Ghost Lake), in Tsiigehtchic. It was a clear but cold day and Caroline had climbed onto a box to look out the window. All of a sudden she saw something dark and moving across Van Tsal. What could it be she wondered? The dark thing started to get closer and closer and suddenly Caroline realized it was a dog team. As they got closer, she realized that it wasn't any old dog team, because as they got closer, Caroline recognized the leader, and sure enough, it was Candice, Old Modeste's fastest dog that was bossy. She watched as her grandfather's dog team came running like the wind across the lake, coming closer and closer to Tsiigehtchic, pulling an empty toboggan. But where were her grandfather and grandmother? Caroline looked at the frozen lake, and beyond the lake to the Mackenzie River just where the Arctic Red River joins it, but Old Modeste and Marcrena, they were nowhere in sight.

Oh, my poor, old grandparents Caroline thought. Why didn't they just come and live in town? It would be much easier for them but no, as old as they were, Old Modeste and Marcrena would not leave the 
land and their dogs. It didn't take long for Caroline to figure out that Candice had dumped Old Modeste and Marcrena off the sled again and left them behind. Here the team came, running into town with a toboggan with no grandfather or grandmother in it! Caroline sat at the window and waited; surely Old Modeste and Marcrena had been dumped off the sled nearby and they would soon make their way into Tsiigehtchic. She told her parents what she had seen and they all waited and waited for Old Modeste and Marcrena to appear. But they never did. Caroline's parents started to get concerned so her father started to get dressed in his parka, boots, and beaver fur mittens and set off to look for them. Just as he got to the bottom of the hill, who did he see but Old Modeste and Marcrena on the other side of Van Tsal walking so very slowly towards him. Old Modeste was carrying a pack on his back. Caroline's father was so very happy to see them, they were safe and unharmed but tired from their long, long walk.

Caroline's father went out to meet Old Modeste and Marcrena and helped them get across Van Tsal. Meanwhile, Caroline's brother had caught Candice and the rest of the dog team and was bringing them down the hill. The team was still pulling the empty toboggan. Her brother had kept the toboggan tied to the team so that Old Modeste and Marcrena could ride to the top of the hill in it. This time, Old Modeste was angry with Candice. Again Candice had not listened to him or followed his instructions. Candice had gone too fast and had dumped him and Marcrena on the trail so very far away and they had to walk so very, very far. Old Modeste was carrying the backpack on his back that Marcrena had been holding for him on the sled. He took from it a little willow branch.

When he finally reached Candice, he took that willow and slapped Candice's rump and said, "Are you going to do that again the next time? No, you are not!"

Candice just looked at him. The willow had not hurt him at all. Usually when you spank a dog for doing something bad, they yelp; but not Candice, Old Modeste was so old and weak, he didn't have the strength to hit him hard. Candice just looked at him. This made Old Modeste madder and madder and he tried harder and harder to spank Candice. Finally Candice just gave a little whimper, hardly loud 
enough for anyone to hear. Exhausted from the walk and trying to discipline Candice, Old Modeste gave up.

He turned to help Marcrena back onto the sled. He would get Candice and the other dogs to pull them up the hill. Meanwhile, Old Modeste took off the pack he had been carrying and laid it gently down on Marcrena's lap. She opened the pack and out jumped five puppies. He had carried those puppies on his back all that way because they had also been dumped out of the sled when Marcrena had fallen off. All Caroline could do was laugh. Her poor old grandfather had packed all those puppies how many miles? And all because his bossy leader, Candice, had been going too fast, not listening to his master and had thrown them off the sleigh-again!

\section{Find The Trail Boy, We Are Lost!}

Annie Koe was born on July 23, 1913, in Fort McPherson. Her mother was Talitha Vitshikk (also known as Talitha Colin) who was the adopted daughter of Old Colin Vitshikk and Annie T'ok Tsal, who became known Annie Colin after her marriage to Old Colin. Annie's farther was Andrew Koe; his parents were Jim Koe and Janet. Andrew and Talitha along with grandparents Old Colin, Annie, Jim, and Janet, taught Annie the ways of the bush well. Family was everything to Annie.

Annie passed away in June of 2007. Before she died, Annie lived in Aklavik. She kept a little box of photos on a shelf in her kitchen. With her tea by her side, she would pull down the box and go through each photo, one by one, lovingly touching the image of the dog or person in the photo, and sharing stories and memories that the photos triggered.

When she was a strong and able-bodied young woman, Annie had her own dog team and she loved her dogs, with all her heart. Along with her parents and grandparents, her dogs were also family to her. When she was a young woman, Annie only thought about her dogs. She needed to think about how to look after them, how to care for them, how to make sure they had enough food. She had to think about her dogs and how to care for them because her dogs also looked after her. They were the ones that would pull her sled or toboggan when she needed to travel. In Annie's younger days, there were no snow machines or roads with cars; if she wanted to go somewhere, her dog 
team needed to take her. Annie's best friends were her dogs. She always looked after them because they, in turn, looked after her.

Annie travelled all over the Teetl'it Gwich'in country with her dog team. She would go far up the Peel River and into the mountains. This she would do with her family because they were searching for caribou. They did this, even in January when it was so very, very cold. But it didn't matter how cold it was, Annie's mother had made her warm fur clothing and so she kept warm.

Sometimes Annie would go miles out of her way to keep her dogs safe. Sometimes she would come to a river or a lake and there would be water on the surface of the ice. If she let her dogs walk or run in the water their paws would freeze, so Annie would go the long way around, just to keep her dogs safe and heathy.

Annie's family was rich with dogs. They usually had three, four, or five dogs in their team. Some other families had as many as three teams of dogs. That would mean they would have sometimes fifteen dogs. That's a lot of dogs to look after and fish for to keep them in food. Annie's family was happy with the number of dogs they had. The more dogs you had, the harder you had to work to feed them all. And you didn't want hungry dogs. They needed to work hard every day for you so they needed to be well fed. As Annie says, a hungry dog is a cranky dog, and they won't work for you. And dogs love to eat fish, lots and lots of fish.

Dogs also need to be loved. They need to be petted and spoken gently to. Annie's dogs only understood Dinjii Zhu' Ginjik, the Gwich'in language, because that's the language she spoke and spoke to her dogs in.

Annie would say to her dogs in her language, "Look! After we eat we're gonna go and move. They said lots of caribou over there on the mountains. If we find them, you're gonna eat lots. We're gonna eat good. So you need to pull and work hard. Listen to me."

Annie's dogs were good to obey her and so they would pull the toboggan and work very hard for her. Once some caribou were killed, they were rewarded with a feast of caribou bones.

Annie would drive her dogs and travel all over, from the mountains beyond Fort McPherson to the delta village of Aklavik. There, she 
would get whatever store supplies she needed and then head back out on the trail. But sometimes, bad weather would quickly come in and she would get stuck on the trail. One time, Annie had left Aklavik one morning. She was heading back to Fort McPherson and by noon a big north wind had come up. Annie knew that a big north wind meant that her trail could be completely blown over in snow within an hour's time and sure enough, as they kept going, the trail was getting harder and harder to see. The snow was blowing and it was hard to see anything at all and on top of that, the trail was blown over completely by the blowing snow. Finally, Annie had to stop. She couldn't see the old trail she had used to come to Aklavik. She looked and looked but couldn't see anything with the blinding snow. What was she going to do? She stood there, her back to the blowing wind, and tried to think. She couldn't see far so she couldn't see any landmarks to tell her where she was. With the blinding snow, and her trail now covered behind her, she didn't know which direction to go. Her dogs lay down in the snow and waited for Annie to give her next command.

All of a sudden Annie thought, I'll untie my lead dog. He will sniff around, find the trail, and then he'll know how to get back to our camp. So, while untying her leader, she spoke softly to him in her language.

"Go and look around for the trail, try and smell out where the trail is. We are lost. We're lost! We lost our trail. And it's snowing and blowing very bad. Look around for the trail. Run around all over. Find our trail for me so we can get safely back to Fort McPherson."

Annie's leader listened to her and understood everything she was saying to him. He now had a very important job, he needed to find the trail and get Annie safely back to town. As soon as she let go of his collar he started to sniff and run from here to there, yelping as he did so. Annie kept on talking to him in her language.

"That's right, find the trail, find the trail that will take us back to Fort McPherson."

All of a sudden her dog started to bark and bark and he was facing a space between some bushes. That was the trail! The dog had found the trail for her. Annie was so happy she praised her leader and then hitched him back up to the team. Off they went, the leader just knew exactly where he was now and the other dogs understood too and started to run faster and faster. Annie's dogs were so good to her. They 
managed to find their way on the trail even though it was covered in snow and it was dark, with no moon or stars to light their way. As Annie says, if you treat your dogs right, they will always lead you back home; treat them right and they will look after you really good.

\section{Meatball (Does Not Come) to the Rescue}

Alfred Semple loves to be out on the land and in the summer and he just loves to be at his fish camp. His fish camp, which he has owned since 1979, is just six kilometres upstream from Aklavik, on the west side of the Peel Channel. It used to be Annie Tyrrell's (also known as Annie Jamieson's) fish camp so it had been used as a fish camp for a long time. Alfred loves to go there and often goes alone because it makes him feel peaceful and he can rest there. He can fish in the Peel River and fishing there is good because that is where the fish come to spawn. It's also a good place to pick berries. Alfred built a small cabin and a fish house there. Sometimes Alfred's wife, Catherine, goes to camp with him and they make dry fish for their children. Alfred is proud that he spends most of his time there. He doesn't spend a lot of time in Aklavik. He says there's not much to do there except to sit and watch television. Out at his camp, there is always something to do, cut wood, and do odd jobs, there's lots of work that keeps him busy all the time at fish camp and Alfred prefers to be busy all the time.

One time, in about 1982, in early September, when alone out at his fish camp, Alfred woke up in the morning and there was a distinct chill in the air. Freeze-up would be coming soon. The bushes had all turned vivid colours of yellow, orange, and red, signalling the end of another season. There was a lot to do to get the camp ready for winter. Yesterday he had pulled his nets from the water, fishing was now over. The fish had come back up the river heading for the Arctic Ocean. He had caught some great Arctic char this year, but now the season was over.

It was still early in the morning; the frosted grasses sparkled like diamonds in the sun. The sun had not yet warmed the ground to melt the frost. Alfred had a big day ahead of him of getting all the things outside his camp put away for the winter. He decided the first thing 
he would do was take up the sheets of plywood he had on the shore. There had been a lot of rain in August and the shore had been terribly muddy. He had put down a few sheets of plywood on the shore so that when he came back from checking his nets, he wouldn't sink into the mud. He had painted the plywood last year thinking he would put it up on a wall of his cabin, but he hadn't gotten around to it so he used it for the shore instead. Didn't matter that it was painted or not, it would be good to walk on to avoid the mud.

Alfred had an old husky dog named Meatball. Meatball might have been old, but in the mornings, when he was hungry, he was like a puppy running around and jumping up on Alfred; he was hungry and wanted some fish to eat. Alfred laughed; Meatball sure was fun to have around. He had been a good dog over the years, he was good on a dog team and good to pull things that were sometimes too heavy for Alfred. Meatball was his only companion and work helper at fish camp at this time of year.

"I'll feed you Meatball as soon as I get this wood up," Alfred said to the dog giving him some strong strokes on his back. But still, Meatball was hungry, jumping and bothering Alfred so Alfred said, "That's enough. I'm going to tie you for a few minutes until I get this wood up, then I'll feed you."

There was a rope tied to the stump of an old tree by the shore. Alfred tied Meatball to that and then he went back to the cabin to get his rubber boots on. He didn't want his feet to get wet in the cold water that he would need to stand in. The shore of the river was only just a foot or so below the land so he was going to have to push the plywood sheets up to the crest of the shoreline knoll. It wouldn't be hard, the plywood was already on a slope from the shore to the top of the little knoll, he just needed to get down into the edge of the water and push the sheets up.

Meatball just barked and barked as Alfred made his way back to the top of the knoll where the plywood rested. He had his rubber boots on and was already to make his way down to the shore. It would be easy, just walk down the plywood like he did every day; except today, it was earlier than usual and the frost had not yet melted on the plywood; the painted wood was still coated in a thin layer of ice. As soon as Alfred put his first foot on the plywood, he realized what a big mistake 
he had made. The rubber boots acted like skis on the icy plywood and down, down, down he slid, right into the river his arms flailing as he tried to steady himself but to no avail. Down into the icy water he fell and when he stopped, he was almost shoulder deep in the water.

Alfred's boots quickly filled with water and were like anchors holding him down. He managed to get his feet out of the boots with some trouble but he was just slipping on the mud on the river bottom. When he managed to reach out and catch the plywood, his hands just slid off. Alfred was starting to panic. How was he going to get ashore before he froze in the water? He was all alone; no one was there to help him except ...

Meatball! Meatball was there and his rope would be long enough for him to come down to the river where Alfred was and then Alfred would be able to hang onto the rope and Meatball would pull him out. Yes, that's how he could get out.

"Meatball, come boy, come on down here boy," Alfred yelled at the dog over and over again. But all Meatball did was stand at the top of the little hill and bark at Alfred. He barked and he barked but he wouldn't come down to the water's edge and help Alfred. Alfred was sure that Meatball was laughing at him and saying, "You are such a fool for standing in the water. You looked just like Jack and Jill going down the hill! I'm not going to help you because I'm cranky that you didn't feed me first." And then Meatball just barked and barked some more at poor, soaking wet Alfred.

Alfred managed to finally pull himself out of the water onto the plywood and, soaking wet, he trudged up the shore. He needed to get back to his cabin and get some dry clothes on and warm up, fast. Shivering and with teeth chattering he muttered to Meatball, who was still just barking and barking at him, "Okay, I've learned my lesson; never expect a hungry dog to help you!" 


\section{The Ribbons Were Flowing with the Wind}

Joan Husky was born somewhere out on the land near Fort McPherson on October 26, 1913. Her parents were Mary Kyikavichik and Jimmy Husky. When Joan's first husband, Philip Ross, passed away in a drowning accident in 1938, she was left to raise her two sons by herself. In 1940, she met and married Edward Nazon and together they lived out on the land. Joan remembers these wonderful times, how happy she was, and recalls some of the adventures they shared when travelling by dog team. The following story is in Joan's words.

"I remember one time when we were going to move or travel for some reason. We left very early in the morning. It was still dark; we just had the light of the moon. We began to travel and when there was a good trail, how the dogs would just gallop, going and through the trees. What a sound it made! I remember all this and it just makes me have memories of joy and happiness; all of those years come back to you. I remember the joy of travelling those years. I also remember travelling at night too. You tried to get to your destination and that meant sometimes, you had to travel late into the night by moonlight. I loved travelling in moonlight, especially in the very early morning. The moon would be so bright on the snow; it was like travelling in the day.

"One year, we were staying at Caribou Lake, and my husband, Edward, said he wanted to go to town, Aklavik, for Christmas. I agreed. It was so close to Christmas, so we started to get ready and we started off from Caribou Lake. We got to Caribou Creek, and we stopped there and made fire. I had made a dog blanket for Edward's harness and standing iron and so he said he was going to fix his harness, put the dog blankets on and put the standing iron on their harness. In no time, he put them on. From then on we started off again. I always travelled ahead of him and in no time I left him behind. My dog team was probably faster because I had a lighter load. When I got to Jackfish Creek, Edward was nowhere in 
sight, so I decided to stop, and wait for him. Once he caught up, he said let's camp here. Oh, I didn't want to camp there.

"So I said to him, 'Why not go to Loche Creek? It's not that far.'

"He thought for a minute then he said, 'Okay, let's go.'

"So we took off to Loche Creek. That's where Marcelline and Pierre Coyen's bush camp was.

"We continued to travel into the night, by moonlight. $\mathrm{Ah}$, it was so beautiful and so peaceful. We got to Loche Creek late and when we arrived there, Granny Marcelline Coyen was there with her husband Pierre and all her children and grandchildren. They were all excited when we arrived. Everybody was just rushing around.

“The kids were yelling, 'Big Edward is here!'

"They were so excited. When we arrived there, the dogs looked so fancy. They looked so nice too because their standing iron on the backs of their necks had ribbons. The ribbons were flowing with the wind and it looked so nice.

"Marcelline told Edward, 'Look at my grandchild and how she looks after you. She takes good care of you and everything. She does everything for you. Look at how nice you look.'

"The next day, we continued on and we arrived at Albert Ross's. They too were getting ready to leave for Aklavik. So, we all continued travelling and while travelling, there was good trail and our dogs were making good time. Once in a while, my brother-in-law, from my first marriage, his name was Tommy, he used to run behind with the dogs. Sometimes he caught up to us and ran behind us but finally our dogs got going really good and we took off from him and left him behind. Our dogs were travelling really well and the trail was good. We got half way. There was a ready-made fireplace halfway 
to Aklavik. We stopped there, made a fire, and we were having something to eat. Then, Buster McLeod arrived. Oh, he had good dogs, big dogs, well-fed dogs. He had a good dog team. He just got there and then somebody else got there and arrived at the fireplace. It was Shorty White. He too had a good team. Shorty White was a very small man and yet he had seven big dogs. I don't know how he handled them! Amongst all the dog teams that arrived, our dogs were ahead. I wanted to keep ahead of everyone. Edward always made me travel ahead of him so as soon as we had something to eat and had drank our tea, I got up and gathered up our things to leave. As soon as I got to my dog team, they all got up ready to go.

"Our sleigh, it was a long toboggan. The purpose of this was to carry loads that we carried out on the land. Sometimes our children sat in there when we moved from one location to another. We had a big load on the two toboggans. We had good dogs, and those days, dog teams were very important. One of our dogs, my dog, when he really wanted to travel, he used to bark every once in a while. He would just give a little bark and when he did this, the rest of the dogs just go. They really travelled then. Of course he did this when we got going and we sure made good travelling time.

"There's a big long lake that you have to cross. When we got to that lake, and we got to the shore on the other side, and I didn't see anyone behind me, I must have really been travelling fast!

"We arrived in Aklavik, our dogs were going fast, the ribbons were just flowing in the wind as we went up the hill to the Hudson's Bay store. There were a lot of people there and as soon as they saw us, they came towards us and stopped our dogs. They were just so amazed at how fancy Edward's dogs and standing irons looked.

"One man looked at the dog blanket and then asked Edward, 'How much are you willing to sell those dog blankets to us for? What would be your price?' 
"Edward told him that they were not for sale, and then we continued on until we got to my parents' house.

"When we arrived at our parents' house, we tied up our dogs and we had to watch closely because they did not know people. We stayed in the bush so they never saw many people. That's why we had to watch them very closely. Because the dogs were not used to seeing people, they were very excited and they were continuously barking. Oh! They were so noisy! Babaa, my father, was afraid they might get loose and if they did get loose they may harm someone.

"He said, 'Go into the warehouse and take out some spikes and go out and nail down their chain so they will not get loose. They will be more secure then'

"My father was just afraid. There were lots of children playing around and people were around and if they got loose, they might harm someone. So, this was the reason why he asked us to spike the chain down more securely.

"During this time, lots of people from town kept coming around. They were after Edward's dog blanket and standing iron. Although he continued to say no to them, they really wanted to buy it. During the night, while we were all asleep, somebody came and took the dog blanket and the standing iron off the harness. The only thing that was left was the dog bells. I guess they really wanted the dog blanket and standing iron for their own! I guess they looked that good. 


\section{Remember Jim and His Gunny Sack Collars?}

Jim Vittrekwa liked to make people laugh and so he would do funny things or play tricks on people, just to make them laugh. Lots of people around Fort McPherson in the Northwest Territories have stories about Jim's antics.

One time, when Jim was a young man and had his own trapline, he thought to himself, why, I'd like to make a fancy collar and harness for my dogs. There was great competition between everyone out on the land to have the very best decorated dog team. Some women would sew moose skin collars for the dogs. Great care was taken by the women who sewed collars that the stitches be almost invisible and placed closely together. Women would also make beautiful harnesses for the dogs and decorate them with ribbons of all colours that would flow in the wind as the dogs raced down the trail. Other women would bead beautiful blankets to cover the dogs and still others would attach ribbons or coloured yarn to the standing iron that would flow out behind the driver. Jim had seen how beautiful Edward Nazon's team looked with the harness, bells, fancy blanket, and ribbons that Joan had made for his team. Gosh, wouldn't it be nice if his team could look like that Jim thought. But, Jim's team had none of this; his dog team was not fancy at all. He decided he was going to change that. Soon it would be time to go to Fort McPherson for Easter. Wouldn't it be wonderful if he could drive his team into town looking all smart and fancy?

Jim unfortunately was not married yet and he didn't have a wife or anyone to sew such beautiful things for his dog team. So, what could he do about decorating his team? Out on the trapline, he didn't have much with him. He started to go through his things, what could he use to make fancy collars for his dogs? He looked and looked and finally, he looked at the gunny sacks that were holding his grub, gun shells, and some wire for snares. That's it he thought! Those gunny sacks would do just the trick.

Now gunny sacks are not very pretty. They are made out of burlap and although they were strong (a big gunny sack can hold about one hundred pounds of supplies), they were brown and not very colourful, and the burlap makes them look very coarse, not smooth 
like moosehide. But Jim didn't think of that. It was something he had that he could use on his team.

Jim emptied out his gunny sacks and packed his supplies carefully in his sleigh and covered them all with a blanket so they would not fall out. Now, how to make collars from these gunny sacks? He didn't have a needle and even if he did, he couldn't sew very well. So Jim kept thinking and thinking about how he could make collars from these gunny sacks. Suddenly, it came to him. He tore the sacks into strips and started to twist them together and then he tied them together into a long piece. He took this long and twisted piece of gunny sack and then tied it to the dog's neck, knotting it on the nape of the dog's neck. When he was done, he proudly surveyed his dog team. What a sight to behold!

The next day Jim headed back to Fort McPherson. Easter was coming and everyone came to town for Easter. All he could think of was what everyone would say when he drove his fancy team into town with them all wearing gunny-sack collars.

He drove the team all day and towards evening, he started to come into town. There were lots of people already there with their fancy dressed dog teams and standing irons. People turned as they heard Jim's team coming into town and everyone just looked and then burst into laughter when they saw how sad, pitiful, and poor his team looked with their brown collars made of gunny sacks and tied up in a knot on the back of their necks. Everyone laughed and laughed. Jim had done it again, his latest antic was just hilarious. From then on, all you needed to say to someone was "Remember Jim and his gunny sack collars" and people would laugh and laugh. Everyone teased Jim about his pitiful looking gunny sack collars on his dog team for years to come. 
These EnTERTAInING SHORT STORIES as told by five Gwich'in Elders accomplish exactly what the Elders and the GSCI wanted from this project-to use documented stories as a means to preserve and promote Gwich'in culture, traditional knowledge, and values. In trying to accomplish this, issues involving multiple translations and transcripts, editing, and adding in the author's observations and prior knowledge to contextualize the stories for the reader, were all issues that needed to be addressed and respectfully considered.

\section{Notes}

1. Gwich'in Social and Cultural Institute, Into the Next Millennium: The Five-Year Plan of the Gwich'in Social and Cultural Institute, 1996-2001 (Tsiigehtchic: Gwich'in Social and Cultural Institute, 1996). The Gwich'in Social and Cultural Institute is now the Gwich'in Tribal Council Department of Cultural Heritage.

2. As noted in Alexander Freund, "From .wav to .txt: Why We Still Need Transcripts in the Digital Age," Oral History 45(1): 33-42.

3. Patricia Leavy, Oral History. Understanding Qualitative Research (Oxford: Oxford University Press, 2011), 123-124.

4. On April 1, 2016, the GSCI became the Department of Cultural Heritage under the Gwich'in Tribal Council.

5. For more information about Treaty 11 see René Fumoleau, As Long As This Land Shall Last: A History of Treaty 8 and Treaty 11, 1870-1939 (Toronto: McClelland and Stewart Limited, 1973). The Gwich'in Comprehensive Land Claim Agreement, Volume I, can be found at http://gwichin.nt.ca/wp-content/uploads/2014/11/GTCComprehensive-Land-Claim.pdf

6. Valerie Yow, Recording Oral History: A Guide for the Humanities and Social Sciences, $2^{\text {nd }}$ ed. (Walnut Creek: AltaMira Press, 2005), 249.

7. Valerie Yow, Recording Oral History: A Guide for the Humanities and Social Sciences, $3^{\text {rd }}$ ed. (Lanhham, Maryland: Rowman \& Littlefield, 2015), 366.

8. The stories in this article have again been worked on by McCartney to give the reader more background information and context to enrich the reader's experience of the story; thus these stories do not appear the exact same way in the forthcoming University of Alberta Press publication. 